\title{
Increased Insulin-Like Growth Factor I Binding to Red Blood Cells of Normal Prepubertal Children ${ }^{1}$
}

\author{
ALAN H. MORRIS, JONI L. JOYCE, AND EDWARD O. REITER
}

Baystate Medical Center, Department of Pediatrics, Springfield, Massachusetts 01199

\begin{abstract}
Young children are growing at a time when circulating levels of IGF-I measured by RIA are generally less than or equal to values in nongrowing aduits. ${ }^{125} \mathrm{I}$ $\mathrm{Thr}^{59}$-IGF-I binding to receptors on conveniently available red blood cells was studied in 33 normal adults (nine males, 24 females) and 13 normal prepubertal children aged 3-10 y (10 boys, three girls; all Tanner stage 1 ). Red blood cell specific binding of ${ }^{125}$ I-Thr ${ }^{59}$-IGF-I was determined by displacement of labeled $\mathrm{Thr}^{59}$-IGF-I by unlabeled $\mathrm{Thr}^{59}$ IGF-I or insulin in a dose-dependent manner. Mean $( \pm$ SEM) ${ }^{125}$ I-Thr ${ }^{59}$-IGF-I specific binding was significantly higher $(p=0.01)$ in prepubertal children than in adults $\left(13.9 \pm 0.7 \%\right.$ versus $11.6 \pm 0.5 \% / 3 \times 10^{9}$ cells $\left./ \mathrm{mL}\right)$. Specific binding did not differ between adult males and females. There was no significant correlation between specific binding and reticulocyte count. Scatchard analysis demonstrated a linear plot. Increased binding to red blood cells in the prepubertal children appeared to be due to an increase in receptor affinity $\left(K_{\mathrm{a}}=4.97 \pm 0.42 \times 10^{8} \mathrm{M}^{-1}\right.$ versus $3.70 \pm 0.41 \times 10^{8} \mathrm{M}^{-1}$; children versus adults; $p=$ $0.03)$. Mean receptor concentrations were not different in children and adults $(64.4 \pm 8.5$ versus $58.0 \pm 5.6$ binding sites/cell). There was a significant positive correlation between ${ }^{125}$ I-Thr ${ }^{59}$-IGF-I specific binding and affinity $(p=$ $0.007, r=0.39$ ). We speculate that the greater specific binding of labeled Thr ${ }^{59}$-IGF-I to red blood cells in prepubertal children may provide a mechanism for enhanced cellular responsiveness to relatively low levels of circulating IGF-I. (Pediatr Res 25:409-413, 1989)
\end{abstract}

IGF-I is a 70 amino acid peptide with growth-promoting activity. Clinically, it is common practice to measure serum or plasma levels of IGF-I by RIA in patients with varying disorders of growth. However, there are frequent and marked discrepancies between levels of IGF-I measured by RIA and growth rate (1-3). Newborns show the greatest growth velocity at any age, have increased levels of growth hormone, yet low serum IGF-I values (4). Prepubertal children grow steadily despite relatively low levels of circulating IGF-I (5).

Variability in IGF-I receptor binding may better explain IGFI activity in the body. IGF-I resistance with decreased IGF-I binding has been suggested as the underlying cause of short stature in some children $(6,7)$. Specific IGF-I receptors are present on a variety of human tissues including fibroblasts (8), mononuclear cells (9), ovary (10), liver (11), brain (12), placenta (13), and erythrocytes (14-16). Erythrocytes are particularly at-

Reccived August 12, 1988; accepted November 28, 1988.

Requests for reprints to Edward O. Reiter, M.D., Baystate Medical Center, Department of Pediatrics, 759 Chestnut Street, Springfield, MA 01199.

I Presented in part at the Society for Pediatric Research, Washington, DC, May tractive to study because they are easily obtainable and require only small sample vol.

In the present study, we compare IGF-I binding to erythrocytes in normal adults and prepubertal children, using a Thr ${ }^{59}$-IGF-I analog. We wished to assess whether young children had evidence for greater binding of IGF-I to help explain their continuing growth.

\section{MATERIALS AND METHODS}

Subjects. We studied 13 normal children, 10 boys and three girls, aged 3 to $10 \mathrm{y}$. All were prepubertal as determined by the method of Tanner, and all were between the 5th and 95th percentiles for height and wt $(17,18)$. We also studied 33 normal nonobese adults, nine men and 24 women, between 20 and 47 $\mathrm{y}$ of age. This study was approved by the Human Subjects Committee of Baystate Medical Center, and all subjects and parents signed an informed consent form before participation.

Materials. Lactoperoxidase iodinated $\left(\mathrm{Thr}^{59}\right)-\mathrm{IGF}-\mathrm{I}$, with a $\mathrm{sp}$ act of $258 \mu \mathrm{Ci} / \mu \mathrm{gm}$, was purchased from Amersham Corp. (Arlington Heights, IL). The product is purified by HPLC to give the monoiodinated peptide. $\mathrm{Thr}^{59}$-IGF-I, $127 \%$ active versus human IGF-I standard by RIA, was purchased from AMGen Biologicals (Thousand Oaks, CA). The IGF-I analog used in this study differs from natural IGF-I only by the substitution of threonine for methionine at position 59. It has similar binding activity in an erythrocyte-binding assay to natural IGF-I $(14,15)$. It also behaves similarly to natural IGF-I in RIA systems (19, 20). Purified pork insulin was kindly provided by Dr. Mary Root of Eli Lilly Co. (Indianapolis, IN). Ficoll-Hypaque was obtained from Sigma Diagnostics (St. Louis, MO).

Separation of erythrocytes. All specimens were obtained between 0800 and 1200 in nonfasting subjects. Blood $(15 \mathrm{cc})$ was collected in sterile heparinized tubes. Cell binding and reticulocyte counts were performed immediately, and serum aliquots were frozen at $-20^{\circ} \mathrm{C}$ until assay. Separation of erythrocytes was accomplished over Ficoll-Hypaque gradient by the method of Gambhir (21). After repeated washes in buffered saline, the erythrocytes were resuspended in Hepes buffer, $\mathrm{pH} 7.4$ (100-mM Hepes, $120-\mathrm{mM} \mathrm{NaCl}, 1.2-\mathrm{mM} \mathrm{MgSO}_{4}, 5 \mathrm{mM}-\mathrm{Na}$ acetate, $10-$ $\mathrm{mM}$ dextrose, $1 \mathrm{mM}$ EDTA, and $1 \% \mathrm{BSA}$ ) to a final mean concentration of $4.88 \times 10^{9}$ cells $/ \mathrm{mL}$ as determined by Coulter counter (Coulter Electronics, Inc., Hialeah, FL). Reticulocytes were determined by staining with methylene blue.

Binding studies. A total of $400 \mu \mathrm{l}$ of erythrocytes were incubated at $4^{\circ} \mathrm{C}$ for $18-24 \mathrm{~h}$ with $50 \mu \mathrm{l}$ of ${ }^{125} \mathrm{I}_{-}$Thr ${ }^{59}$-IGF-I (20 000 $30000 \mathrm{cpm}$ ) alone or with the addition of unlabeled IGF-I analog at varying concentrations between 2.5 and $160 \mathrm{ng} / \mathrm{mL}$. The final vol was $500 \mu \mathrm{L}$. After incubation, duplicate $200-\mu \mathrm{L}$ aliquots of suspension were layered over $200 \mu \mathrm{L}$ of cold $2 \% \mathrm{BSA}$ Hepes buffer in plastic microtubes. After microcentrifugation in a Beckman Microfuge (Beckman Instruments, Inc., Palo Alto, CA), supernatants were discarded and radioactivity of the pellets 
measured. Nonspecific binding was defined as that radioactivity that remained in the presence of $1 \mu \mathrm{g} / \mathrm{mL}$ of IGF-I analog and was subtracted from the total binding determination to yield specific binding. Nonspecific binding was $6.3 \pm 0.4 \%$ (mean \pm SEM) of the total radioactivity added. Results were normalized to $3 \times 10^{9}$ cells $/ \mathrm{mL}$. Intra- and interassay coefficients of variation were $3.1 \%$ and $16.5 \%$, respectively.

In five normal nonobese adults, specificity of ${ }^{125} \mathrm{I}-\mathrm{Thr}^{59}$-IGF-I binding for IGF-I receptors was measured by the ability of unlabeled insulin $\left(2.5-10,000 \mathrm{ng} / \mathrm{mL}\right.$ to inhibit ${ }^{125} \mathrm{I}-\mathrm{Thr}^{59}-\mathrm{IGF}-\mathrm{I}$ binding.

Specific IGF-I levels were measured by RIA at Endocrine Sciences (Tarzana, CA). The RIA was conducted using serum samples after chromatography on Sephadex G-50 columns in $0.25-\mathrm{M}$ formic acid. This acid chromatography step yields a fraction containing over $95 \%$ of the applied IGF-I activity with no detectable binding protein activity (22).

Statistical analysis. Analysis of ligand binding data was performed using the Ligand-PC curve fitting and data analysis software program developed by Munson and Rodbard at the National Institutes of Health. Statistical significance for all data was calculated by the 2-tailed Student's $t$ test with appropriate assessment for equality of variance and linear regression analysis.

\section{RESULTS}

In the prepubertal children, the specific ${ }^{125}{ }^{12}-T_{h}{ }^{59}$-IGF-I binding to red blood cells of $13.9 \pm 0.7 \%$ (mean \pm SEM, with a range from 9.2 to $19 \%)$ was significantly higher $(p=0.01)$ than the $11.6 \pm 0.5 \%$ value for the adults (range, $7.1-17.5 \%$ ) (Table 1).

Table 1. Characteristics of ${ }^{125} I-T h r^{59}-I G F-I$ binding to erythrocytes from normal adults and prepubertal children*

\begin{tabular}{|c|c|c|c|c|}
\hline Subject & $\begin{array}{c}{ }^{125} \mathrm{I}-\mathrm{Th} \mathrm{r}^{59} \text {-IGF-I } \\
\text { specific binding } \\
(\%)\end{array}$ & $\underset{\left(\times 10^{8} \mathrm{M}^{-1}\right)}{\mathrm{K}_{\mathrm{a}}}$ & $\begin{array}{l}\text { No. } \\
\text { binding } \\
\text { sites/ } \\
\text { erythrocyte }\end{array}$ & $\begin{array}{l}\text { IGF-I } \\
(\mu / \mathrm{ml})\end{array}$ \\
\hline $\begin{array}{c}\text { Prepubertal } \\
\text { children }\end{array}$ & $13.9 \pm 0.7 \dagger$ & $4.97 \pm 0.42 \dagger$ & $64.4 \pm 8.5$ & $0.92 \pm 0.10$ \\
\hline$(n=13)$ & $p=0.01$ & $p=0.03$ & NS & NS \\
\hline $\begin{array}{l}\text { Adults } \\
(n=33)\end{array}$ & $11.6 \pm 0.5$ & $3.70 \pm 0.41$ & $58.0 \pm 5.6$ & $1.1 \pm 0.06$ \\
\hline
\end{tabular}

$*$ All values mean $\pm \mathrm{SEM}$.

$\dagger p<0.05$ compared to adult.
Specific binding did not differ between adult males and females, nor was there a significant correlation between specific binding and reticulocyte count (range, $0.3-3.0 \%$ ) in either the adults or children (data not shown). Serum IGF-I levels did not differ between the two groups; all subjects had levels in the normal range for age.

Figure 1 shows the displacement of ${ }^{125} \mathrm{I}-\mathrm{IGF}-\mathrm{I}$ analog by increasing concentrations of either unlabeled IGF-I analog or insulin in adults and children. At each concentration of IGF-I, there was significantly more displacement of the tracer in children than in adults. Half maximal displacement occurred at an IGF-I concentration of about $20 \mathrm{ng} / \mathrm{mL}$ in the adults and at about $10 \mathrm{ng} / \mathrm{mL}$ in the children. An approximately 500-fold concentration of insulin over that of unlabeled $\mathrm{Thr}^{59}$-IGF-I was required to inhibit ${ }^{125} \mathrm{I}-\mathrm{Th} \mathrm{r}^{59}$-IGF-I binding.

Scatchard analysis revealed linear plots for both prepubertal children and adults (Fig. 2). The mean value, $4.97 \times 10^{8} \mathrm{M}^{-1}$, for the affinity constant in the prepubertal children was significantly greater $(p=0.03)$ than in adults, $3.70 \times 10^{8} \mathrm{M}^{-1}$ (Table 1). There was no difference for receptor concentration values between adults $(58.0 \pm 5.6$ sites/red blood cell), and children $(64.4 \pm 8.5)$.

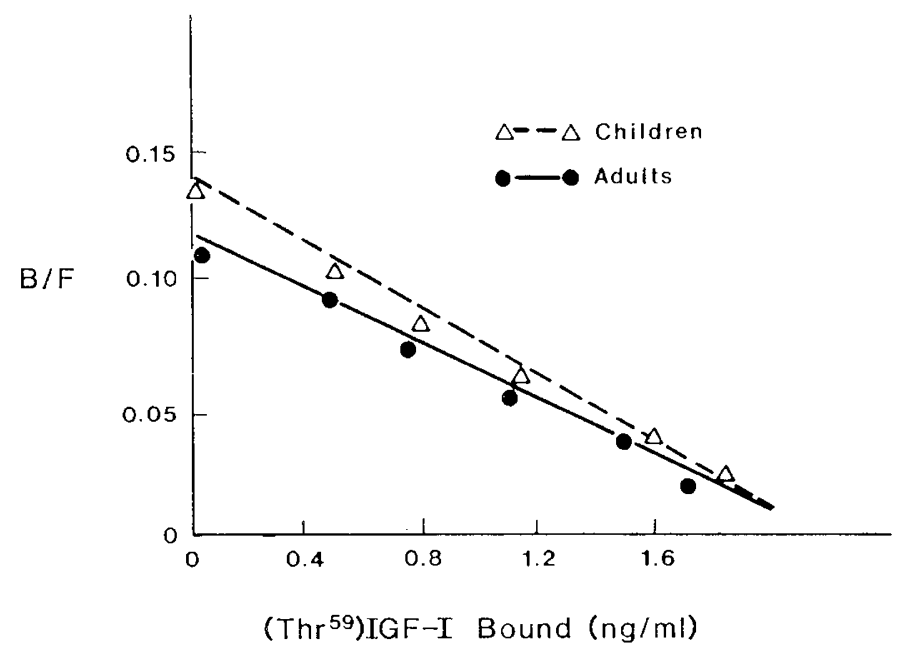

Fig. 2. Scatchard analysis of ${ }^{125} \mathrm{I}-\mathrm{Th} \mathrm{r}^{59}-\mathrm{IGF}-\mathrm{I}$ binding to erythrocytes from normal adults $(n=33)$ and prepubertal children $(n=13)$. Mean values for the individual Scatchard plots within each group are shown.

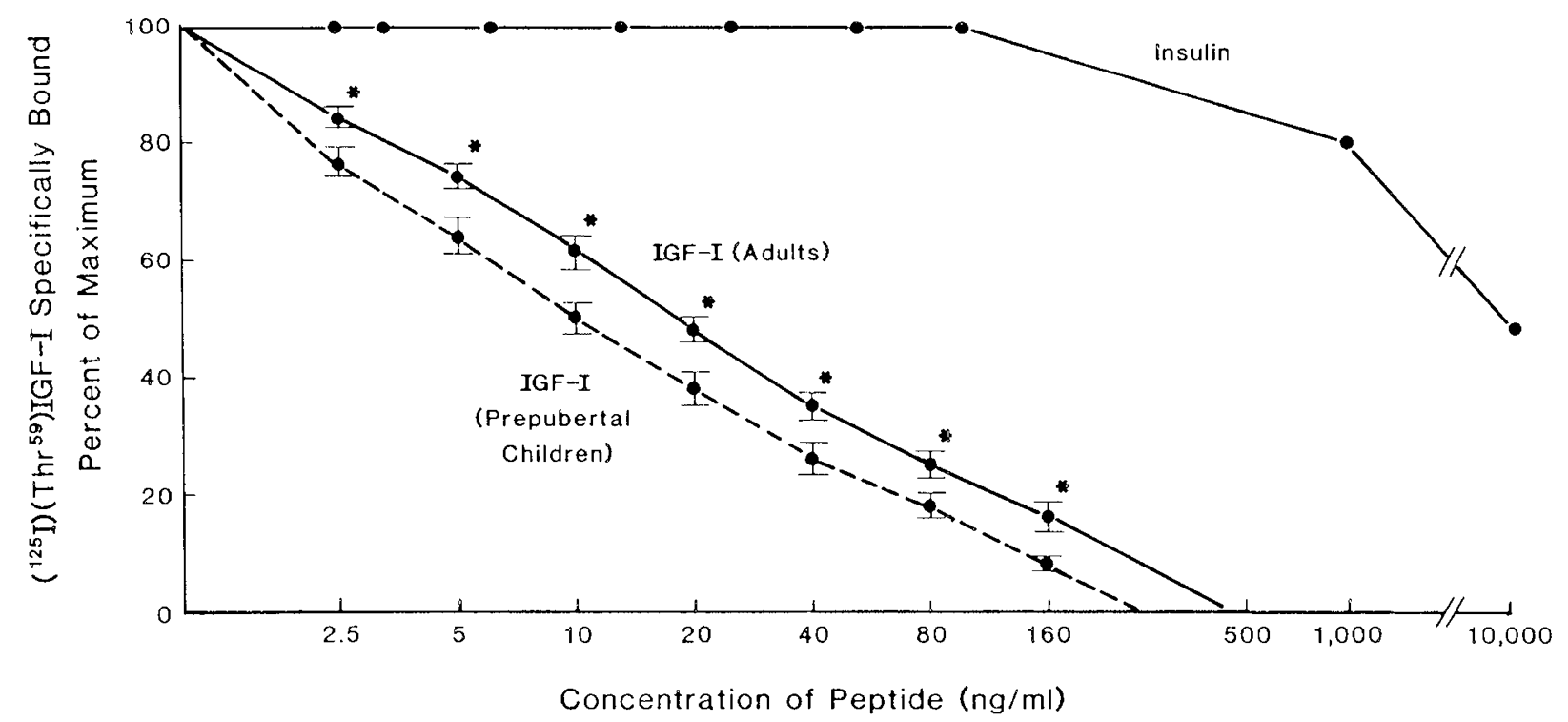

Fig. 1. Competitive inhibition of ${ }^{125} \mathrm{I}-\mathrm{Th} \mathrm{r}^{59}$-IGF-I to human erythrocytes by $\mathrm{Thr}^{59}$-IGF-I and insulin. Each point represents the mean \pm SEM for IGF-I binding and the mean $(n=5)$ for insulin binding. ${ }^{*} p<0.05$ adults $(n=33) v s$. prepubertal children $(n=13)$. 
There was a highly significant correlation $(p=0.007, r=0.39)$ between specific ${ }^{125} \mathrm{I}$-Thr ${ }^{59}$-IGF-I binding and the affinity constant when all subjects were assessed (Fig. 3). This correlation exists within the adult group alone, but does not reach statistical significance in the data from the prepubertal children. However, there was no relation between labeled $\mathrm{Thr}^{59}$-IGF-I binding and circulating serum IGF-I levels (Fig. 4) or receptor concentration (data not shown).

\section{DISCUSSION}

Previous studies have demonstrated specific IGF-I binding to red blood cells (14-16). As further evidence, $\alpha$ IR-3, a mouse
$\mathrm{MAb}$ that specifically binds to the type 1 IGF-I receptor, significantly inhibits IGF-I binding to the erythrocyte (23). We have also confirmed the specificity of ${ }^{125} \mathrm{I}^{-T h} \mathrm{~T}^{59}$-IGF-I binding to erythrocytes by showing that insulin was only about $0.2 \%$ as potent as unlabeled $\mathrm{Thr}^{59}$-IGF-I in inhibiting tracer binding.

Although the mature red blood cell has no nucleus, previous studies with insulin binding show that it is an acceptable tissue for evaluating changes in insulin receptor affinity and long-term changes in receptor concentration (24). Given the significant structural homology between insulin and IGF-I and their respective receptors $(25,26)$, erythrocytes also should be valid to study IGF-I binding. Additionally, Izumi et al. (14) described patients with insulin receptor abnormalities who have decreased numbers

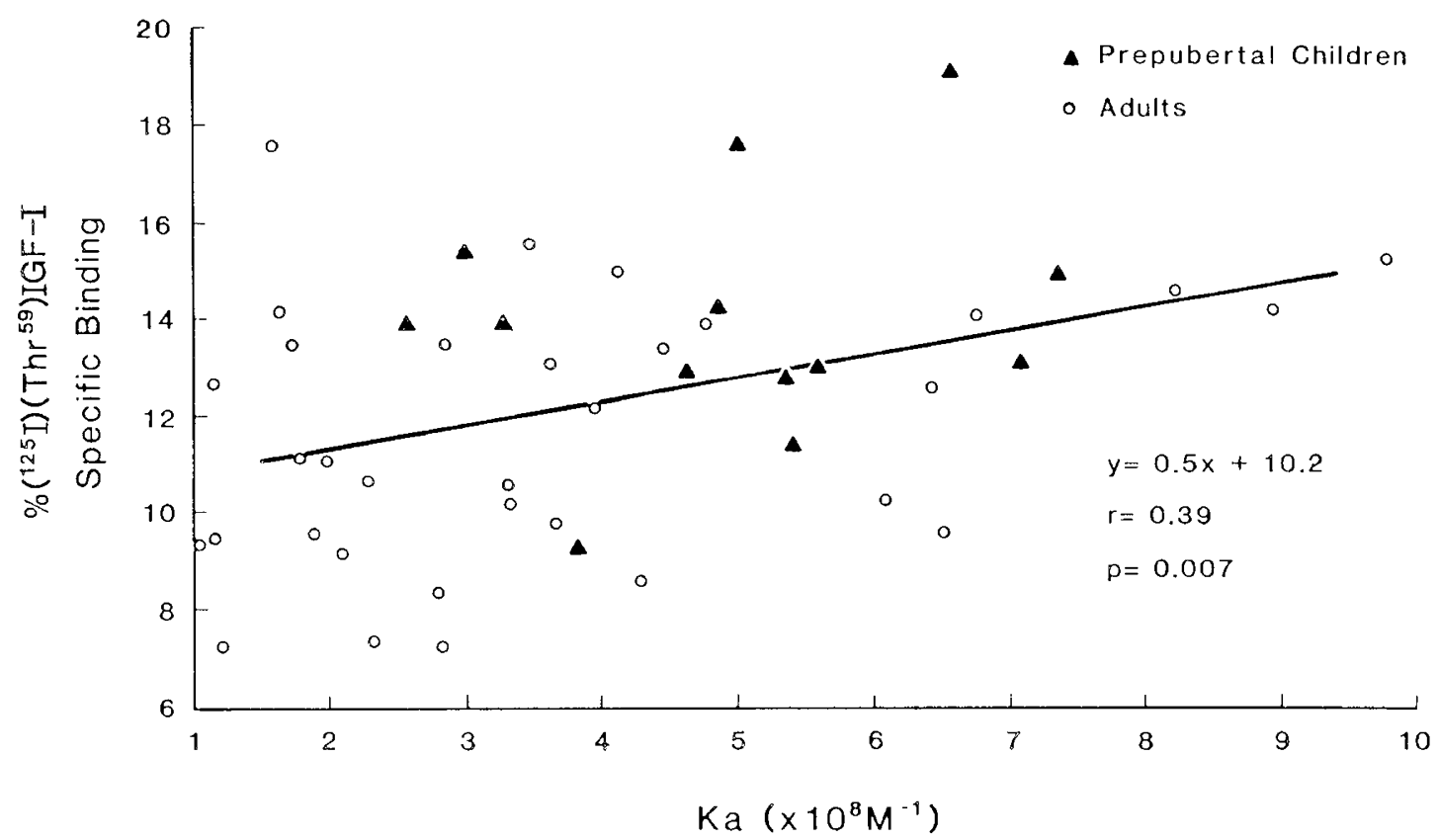

Fig. 3. The relationship between receptor affinity and specific ${ }^{125} \mathrm{I}-\mathrm{Th} \mathrm{r}^{59} \mathrm{IGF}-\mathrm{I}$ binding in normal adults $(n=33)$ and prepubertal children $(n=$ 13). The correlation coefficient was statistically significant $(r=0.39 ; p=0.007)$.

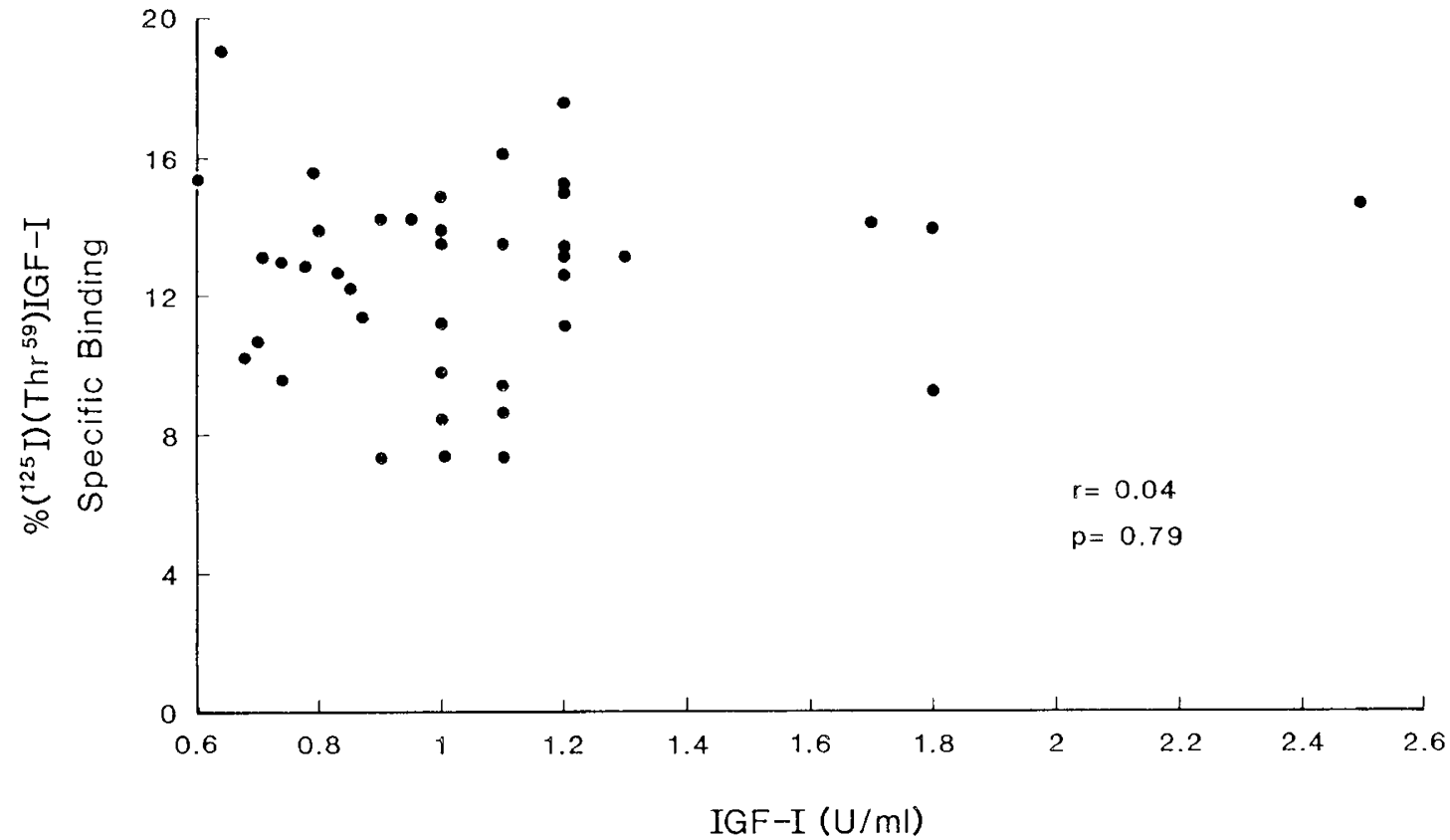

Fig. 4. The relationship between serum IGF-I levels and specific ${ }^{125} \mathrm{I}-\mathrm{Th} \mathrm{r}^{59}$-IGF-I binding to erythrocytes from adults and prepubertal children. The correlation coefficient was not statistically significant. 
of both insulin and IGF-I erythrocyte receptors. If an intervention is planned, it should still be possible to measure short-term changes in receptor affinity even though generation of any new membrane protein would be limited in the circulating red blood cells. An appropriate amount of time would have to pass for the replenishment of new erythrocytes from the bone marrow, however, before evaluating any changes in receptor number (27).

We looked for any effects of red blood cell age on ${ }^{125}$ I-Thr ${ }^{59}$ IGF-I binding but found no correlation between reticulocyte count and specific binding. Hizuka et al. (15) studied seven normal adults and did not see increased IGF-I binding over a range of reticulocyte counts from $0.1-1.1 \%$ even though they found that ${ }^{125} \mathrm{I}-\mathrm{IGF}-\mathrm{I}$ binding was greater in younger than older erythrocytes of individual subjects. In a study by Kosmakos et al. (28), looking at insulin binding to erythrocytes, a significant positive correlation was seen between reticulocyte count and ${ }^{125} \mathrm{I}$ insulin binding. However, many of their subjects were anemic, and over one-third had reticulocyte counts greater than $10 \%$.

Scatchard analysis revealed a linear plot, a finding which has been reported by other investigators studying IGF-I binding to erythrocytes $(15,23)$. Mean ${ }^{125} \mathrm{I}$-Thr ${ }^{59}$-IGF-I binding was $20 \%$ greater in the prepubertal children than adults due to a $32 \%$ greater receptor affinity. Such maturity-related differences in IGF-I binding have been reported previously by other investigators. Izumi et al. (14) studied 33 normal adults between 18 and 81 y of age and showed that erythrocytes from the younger patients had greater ${ }^{125}$ I-Thr ${ }^{59}$-IGF-I binding. Their reported total specific binding data were similar to the adult values found in our study. Chernausek et al. (11), have reported greater binding of IGF-I by fetal liver membranes than by adult membranes. Studies of cultured human fibroblasts have shown greater IGF-I binding and affinity in cultures derived from fetal donors than those from elderly subjects (29). Rosenfeld et al. (9) reported that specific binding of IGF-I by newborn mononuclear cells was $71 \%$ higher than that of adult controls. In that study, however, the increased binding appeared to be due to an increase in receptor concentration. Finally, previous experience with insulin has shown significantly greater insulin binding to cord erythrocytes than to erythrocytes from older subjects (30).

Although there was a positive correlation between specific ${ }^{125} \mathrm{I}$ Thr ${ }^{59}$-IGF-I binding and receptor affinity, there was no relationship between serum IGF-I levels and specific binding or receptor number. This is not surprising given that circulating levels of IGF-I may have little bearing on IGF-I concentrations or, presumably, effects at the tissue level (31). Hizuka (15) reports an inverse correlation between serum IGF-I levels and receptor number but only when looking at a group of adults that included not only normal subjects, but those with acromegaly and hypopituitarism.

When attempting to look at the clinical significance of IGF-I binding to erythrocytes relative to growth, one needs to make the assumption that red blood cell-IGF-I binding reflects the state of the IGF-I receptors at the growth plate level. A number of reports $(8-11,13)$ on varying types of cells demonstrate functional similarities of IGF-I binding to its receptor. Increased ${ }^{125} \mathrm{I}$-Th ${ }^{59}$ binding in prepubertal children, which can be explained by increased receptor affinity, may provide a mechanism for enhanced cellular responsiveness to relatively low circulating levels of IGF-I, although our studies do not prove such speculation. The fact that young children are growing and have increased IGF-I binding, whereas adults are not growing and, more importantly, show no acromegaloid changes and have decreased IGFI binding suggests physiologic relevance. We did not investigate type 2 IGF receptors in adults and prepubertal children, so we cannot rule out the possibility that differences in distribution of those receptors could alter the described changes in affinity.

Rosenfield et al. (32), in their study of normal teenage boys, have reported that maximal serum IGF-I levels, measured by RIA, were observed only after peak pubertal growth velocities had been reached and remained above adult levels even when the boys almost stopped growing. We are now beginning to measure ${ }^{125}$ I-Thr ${ }^{59}$-IGF-I-erythrocyte binding in normal pubertal subjects in the hope that it may be a more sensitive and physiologic method of measuring IGF-I activity during the normal pubertal process than by RIA determination.

\section{REFERENCES}

1. Van Vliet G, Styne DM, Kaplan SL, Grumbach MM 1983 Growth hormone treatment for short stature. N Engl J Med 309:1016-1022

2. Gertner JM, Genel M, Gianfredi SP, Hintz RL, Rosenfeld RG, Tamborlane WV, Wilson DM 1984 Prospective clinical trial of human growth hormone in short children without growth hormone deficiency. J Pediatr 104:172176

3. Plotnick LP, Van Meter QL, Kowarski AA 1983 Human growth hormone treatment of children with growth failure and normal growth hormone levels by immunoassay: lack of correlation with somatomedin generation. Pediatrics $71: 324-327$

4. Kaplowitz PB, D'Ercole AJ, Van Wyk JJ, Underwood LE 1982 Plasma somatomedin-C during the first year of life. J Pediatr 100:932-934

5. Phillips LS, Vassilopoulou-Sellin R 1980 Somatomedins. N Engl J Med 302:438-446

6. Van Obberghen-Schilling EE, Rechler MM, Romanus JA, Knight AB, Nissley SP, Humbel RE 1981 Receptors for insulin-like growth factor I are defective in fibroblasts cultured from a patient with leprechaunism. J Clin Invest 68:1356-1365

7. Bierich JR, Moeller H, Ranke MB, Rosenfeld RG 1984 Pseudopituitary dwarfism due to resistance to somatomedin: a new syndrome. Eur J Pediatr 142:186-188

8. Rosenfeld RG, Dollar LA 1982 Characterization of the somatomedin-C insulin like growth factor (Sm-C/IGF-I) receptor on cultured human fibroblast monolayers: regulation of receptor concentrations by Sm-C/IGF-I and insulin. J Clin Endocrinol Metab 55:434-440

9. Rosenfeld R, Thorsson AV, Hintz RL 1979 Increased somatomedin receptor sites in newborn circulating mononuclear cells. J Clin Endocrinol Metab 48:456-461

10. Bayer S, Seibel M, Gates G, Moses A, Flier J 1986 Identification of insulinlike growth factor receptors in human granulosa cells. Scientific Program and Abstracts for the 33rd Annual Meeting of the Society for Gynecologic Investigation: 76(abstr)

11. Chernausek SD, Beach DC, Banach W, Sperling MA 1987 Characteristics of hepatic receptors for somatomedin-C/insulin-like growth factor I and insulin in the developing human. J Clin Endocrinol Metab 64:737-743

2. Sara VR, Hall K, Von Holtz H. Humbel R, Sjogren B, Wetterberg L 1982 Evidence for the presence of specific receptors for insulin-like growth factors 1 (IGF-1) and 2 (IGF-2) and insulin throughout the adult human brain. Neurosci Lett 34:39-44

13. Marshall RN, Underwood LE, Voina SJ, Foushee DB, Van Wyk JJ 1974 Characterization of the insulin and somatomedin-C receptors in human placental membranes. J Clin Endocrinol Metab 39:283-292

14. Izumi T Kasuga M, Kadowaki T, Hizuka N, Takaku F, Akanuma Y 1986 Characteristics of human erythrocyte insulin-like growth factor receptors. J Clin Endocrinol Metab 62:1206-1212

15. Hizuka N, Takano K, Tanaka I, Honda N, Tsushima T, Shizume K 1985 Characterization of insulin-like growth factor I receptor on human erythrocytes. J Clin Endocrinol Metab 61:1066-1070

16. Polychronakos C, Guyda HJ, Posner BI 1983 Receptors for the insulin-like growth factors on human erythrocytes. J Clin Endocrinol Metab 57:436438

17. Marshall WA, Tanner JM 1969 Variations in pattern of pubertal changes in girls. Arch Dis Child 44:291-303

18. Marshall WA, Tanner JM 1970 Variations in pattern of pubertal changes in boys. Arch Dis Child 45:13-23

19. Rosenfeld R, Conover C, Hodges D, Lee P, Misra P, Hintz R, Li CH 1987 Heterogeneity of insulin-like growth factor-I affinity for the insulin-like growth factor-II receptor: comparison of natural, synthetic and recombinant DNA-derived insulin-like growth factor-I. Biochim Biophys Res Commun 143:199-205

20. Schalch D, Reismann D, Emler C, Hunbel R, Li CH, Peters M, Lau E 1984 Insulin-like growth factor $\mathrm{I} /$ somatomedin $\mathrm{C}(\mathrm{IGF}-\mathrm{I} / \mathrm{SmC})$ : comparison of natural, solid phase synthetic and recombinant DNA analog peptides in two radioligand assays. Endocrinology 115:2490-2492

21. Gambhir KK, Archer JA, Bradley CJ 1978 Characteristics of human erythrocyte insulin receptors. Diabetes 27:701-708

22. Hintz RL 1984 Plasma forms of somatomedin and the binding protein phenomenon. Clinics in Endocrinology and Metabolism 13:31-42

23. Catanese VM, Grigorescu F, King GL, Kahn CR 1986 The human erythrocyte insulin-like growth factor I receptor: characterization and demonstration of ligand-stimulated autophosphorylation. J Clin Endocrinol Metab 62:692699

24. Ward GM, Harrison LC 1986 Structure of the human erythrocyte insulin receptor. Diabetes 35:101-105

25. Rinderknecht E, Humbel RE 1978 The amino acid sequence of human insulinlike growth factor I and its structural homology with proinsulin. J Biol Chem $253: 2769-2776$ 
26. Massague J, Czech MP 1982 The subunit structures of two distinct receptors for the insulin-like growth factor I and II and their relationship to the insulin receptor. J Biol Chem 257:5038-5045

27. Spanheimer RG, Bar RS, Ginsberg BH, Peacock ML, Martino I 1982 Comparison of insulin binding to cells of fed and fasted obese patients: results in erythrocytes and monocytes. J Clin Endocrinol Metab 54:40-47

28. Kosmakos FC, Nagulesparan M, Bennett PH 1980 Insulin binding to eryth rocytes: a negative correlation with red cell age. J Clin Endocrinol Metab $51: 46-50$

29. Clemmons DR, Elgin RG, James PE 1986 Somatomedin-C binding to cultured human fibroblasts is dependent on donor age and culture density. $\mathbf{J}$ Clin Endocrinol Metab 63:996-1001

30. Hendricks SA, Lippe BM, Kaplan SA, Landaw EM, Hertz D, Scott M 1981 Insulin binding to erythrocytes of normal infants, children, and adults: variation with age and sex. J Clin Endocrinol Metab 52:969-974

31. Orlowski CC, Chernausek SD 1988 Discordance of serum and tissue somatomedin levels in growth hormone-stimulated growth in the rat. Endocrinology 122:44-49

32. Rosenfield RL, Furlanet1o R, Bock D 1983 Relationship of somatomedin-C concentrations to pubertal changes. J Pediatr 103:723-728 